University of Nebraska - Lincoln

DigitalCommons@University of Nebraska - Lincoln

$1-2011$

\title{
Socializing Messages in Blue-Collar Families: Communicative Pathways to Social Mobility and Reproduction
}

\author{
Kristen Lucas \\ University of Nebraska-Lincoln, kristen.lucas@louisville.edu
}

Follow this and additional works at: https://digitalcommons.unl.edu/commstudiespapers

Part of the Inequality and Stratification Commons, Organizational Communication Commons, and the Work, Economy and Organizations Commons

Lucas, Kristen, "Socializing Messages in Blue-Collar Families: Communicative Pathways to Social Mobility and Reproduction" (2011). Papers in Communication Studies. 14.

https://digitalcommons.unl.edu/commstudiespapers/14

This Article is brought to you for free and open access by the Communication Studies, Department of at DigitalCommons@University of Nebraska - Lincoln. It has been accepted for inclusion in Papers in Communication Studies by an authorized administrator of DigitalCommons@University of Nebraska - Lincoln. 
Published in Western Journal of Communication 75:1 (January-February 2011), pp. 95-121; DOI: 10.1080/10570314.2010.536964 Copyright @ 2011 Western States Communication Association; published by Routledge/Taylor \& Francis Group. Used by permission.

\title{
Socializing Messages in Blue-Collar Families: \\ Communicative Pathways to Social Mobility and Reproduction
}

\author{
Kristen Lucas
}

\begin{abstract}
This study explicitly links processes of anticipatory socialization to social mobility and reproduction. An examination of the socializing messages exchanged between blue-collar parents $(n=41)$ and their children $(n=25)$ demonstrate that family-based messages about work and career seldom occur in straightforward, unambiguous ways. Instead, messages take several paths (direct, indirect, ambient, and omission). Further, the content of messages communicated along these paths often is contradictory. That is, sons and daughters receive messages that both encourage and discourage social mobility. Ultimately, these individuals must negotiate the meanings of family-based anticipatory socialization communicated to them through a mix of messages.
\end{abstract}

Keywords: anticipatory socialization, social class, social mobility, social reproduction

Organizational socialization remains one of the most well-developed areas of research in the organizational communication discipline. However, surprisingly little research explicitly has linked processes of organizational socialization to broader sociological processes of social mobility and reproduction. In the same vein, social mobility and social reproduction have been the most extensively investigated issues in American sociology for generations (Rytina, 1992). Yet while these phenomena have been tied, at least implicitly, to communication processes (Bertaux \& Thompson, 1997; Willis, 1977), very little research has foregrounded the role of communication. Clearly there is a need for establishing a strong and explicit connection between these two areas.

Kristen Lucas (PhD, Purdue University) is Assistant Professor of Communication Studies at the University of Nebraska-Lincoln. Correspondence to: Kristen Lucas, Department of Communication Studies, 436 Oldfather Hall, University of Nebraska-Lincoln, Lincoln, NE 68588-0329, USA; email klucas3@unl.edu 
Moreover, organizational socialization and social mobility/reproduction are significant because they are inherently linked to vocational choice, which, in turn, is linked to material and affective outcomes that impact individuals and families. For example, the career someone pursues will determine salary, benefits, job security, opportunities for advancement, working conditions, level of autonomy and creativity allowed, risk of injury, job satisfaction, children's life chances, and more. Therefore, the process by which individuals are socialized in ways that present some career choices as more desirable and/or attainable than others-particularly when those choices ultimately are tied to social mobility and reproduction-should be of great concern.

This study addresses the reciprocal disconnect between social mobility/reproduction and organizational socialization by placing communication at the center of this important and consequential sociological issue. The aim of this research is to examine the work- and career-related messages exchanged in blue-collar families and how these messages ultimately influence mobility and reproduction patterns. Ultimately, I argue socializing communication in blue-collar families seldom manifests itself in clear, unequivocal messages whereby some children are encouraged to be upwardly mobile and others to reproduce the social structure. Instead, contradictory messages of both mobility and reproduction coexist within working-class families. Further, individuals rely heavily on contextual cues to assist them in negotiating the meanings of the socializing messages to which they are exposed.

\section{Situating the Study}

In this section, I situate this study within the relevant literature on social mobility/ reproduction and organizational socialization. At the outset, it is important to emphasize that this study does not position communication merely as a tool for achieving sociological outcomes. Instead, it positions social mobility and reproduction as phenomena constituted equally by material structures and inherently communicative processes. To begin, I define social mobility and reproduction. Next, I review extant literature on organizational socialization, focusing primarily on family-based socialization studies. In particular, I describe what is known about the various message paths socializing communication can take. Finally, I draw connections between organizational socialization content and its connection to social mobility and reproduction patterns.

\section{Social Reproduction and Mobility}

Social reproduction can be understood both narrowly (i.e., "occupational following" or holding the same occupation as a parent) and more broadly (e.g., holding a position with the same socioeconomic index, occupational prestige score, and/ or functional category of a parent's occupation) (Laband \& Lentz, 1985; Rytina, 1992). Rytina (1992) explains that decades of empirical sociological research have amply documented this "status continuity." In other words, sons are concentrated 
in occupations "close" to those of their fathers (sociological research tends to focus more on men than women). In its narrow sense, social reproduction remains prevalent in many fields such as firefighting (Myers, 2005), factory work (Gibson \& Papa, 2000), and agriculture (Pitts, Fowler, Kaplan, Nussbaum, \& Becker, 2009), as well as higher end credentialed occupations such as law, medicine, and politics (Laband \& Lentz, 1985; Perrucci \& Wysong, 2003). In its broader sense, social reproduction is evident in patterns of college success. Across the board, college students whose parents attended or graduated from college were far more successful than their peers whose parents did not attend college (Chen \& Carroll, 2005; Lareau \& Conley, 2008). What this means in terms of social mobility and reproduction is that first-generation college students (presumably those from working-class families) have a more difficult time fulfilling the educational requirements largely necessary for success in white-collar professions and, consequently, are hindered from achieving social mobility.

There are different explanations as to why social reproduction persists. First, Perrucci and Wysong (2003) contend that members of the privileged class, in addition to financial resources, offer their children the social and cultural capital that ease their entry into specific occupations and/or organizations. They are able to use their professional and social networks to pull strings for admission into prestigious universities and to arrange for high-status internships and jobs with business colleagues.

A second explanation entails child-rearing practices. That is, working-class families socialize their children differently from the ways middle- and upper-class families do. Kohn (1969) argues that parents have a tendency to reproduce the values and power structures of their respective workplaces in their homes. Therefore, blue-collar parents - who punch time clocks, defer to bosses, and have little autonomy on the job-raise their children in ways that emphasize respect for authority and compliance with orders ("conformity values"). In contrast, white-collar parents, whose jobs offer more autonomy, raise their children to develop skills such as decision-making, critical thinking, and initiative ("self direction values"). These differences result in the reproduction of class-based work orientations that condition, so to speak, children for occupations similar to those of their parents.

A third explanation for social reproduction is that members of the working classes have lower achievement aspirations and expectations. Fifty years ago, it was demonstrated that the career aspirations of mill workers' children were significantly lower than those of white-collar workers' children even though they resided in the same community (Morland, 1960). Although certainly dated, the same argument is forwarded today. For example, a recent study shows that poor children projected their likelihood of career success to be much less than that of their middle-class peers (Weinger, 2000).

In contrast to social reproduction, social mobility is the vertical movement of individuals within a stratified social system from their social class of origin to a new social class. While social mobility often has upward connotations (Bertaux \& Thompson, 1997; Serravallo, 2004), it also includes downward mobility (Newman, 1999). When it comes to upward social mobility, there are countless examples of the sons 
and daughters of blue-collar workers succeeding in white-collar and middle/upperclass professions (e.g., Lubrano, 2004; Sennett \& Cobb, 1972). Thus, individual agency can compensate for structural constraints that limit possibilities for mobility. More than 40 years ago, Simpson (1962) showed that family communication can offset social class origin and associated disadvantages in terms of career ambition. He concluded that "a working-class boy [sic] is relatively likely to seek advanced education and occupational mobility if his parents urge him to do so, and unlikely to seek mobility if his parents do not exert pressure in this direction" (p. 518). This "pressure" came in the form of messages from parents. Therefore, Simpson's research points to the centrality of communication in both contributing to reproduction and encouraging mobility. More recently, Serravello (2004) examined processes of "mobility socialization," in which working-class parents communicate a set of values that encourage their children to pursue college education, nonmanual occupations, and a middleclass lifestyle.

Social mobility offers important benefits to individuals, especially those from working-class families. First, there are significant material benefits. On average, college graduates earn $70 \%$ more than high school graduates, they are $20 \%$ more likely to have an employer-provided pension, and 30\% more likely to have employer-provided health insurance (Mishel, Bernstein, \& Shierholz, 2009). Second, white-collar and/or middle-class occupations generally are more stable than blue-collar and/or working-class occupations. Blue-collar work provides less long-term financial stability and security, as work sites oftentimes are prone to strikes, layoffs, seasonal slowdowns, and other kinds of risks that expose workers to financial hardship. In addition, blue-collar workers are more likely to be in contingent or nonstandard work relationships (Ansberry, 2003; Mishel et al., 2009; Perrucci \& Wysong, 2003). Third, and most importantly, the world of work is changing and there are better prospects for white-collar work in the new economy. The U.S. recession of the 1980s and the ensuing deindustrialization were responsible for the permanent disappearance of more than 3 million blue-collar jobs (Bluestone \& Harrison, 1982). Whereas the goods-producing sector of the economy accounted for $28 \%$ of total jobs in 1979, that number has dwindled to $17 \%$ (Mishel et al., 2009). Further, the most highly paid blue-collar jobs (i.e., in mining and manufacturing) have dropped by more than half. Today, the occupations with the best prospects are those that require higher education, computer skills, and other competencies related to knowledge work. Finally, in addition to material benefits, white-collar occupations generally are perceived as more prestigious and well-regarded in society than blue-collar jobs (Clair, 1996; Gilbert, 2008). ${ }^{1}$

The benefits afforded by social mobility should be viewed with caution, however. That is, social mobility from working-class and blue-collar origins to middle/ upper-class and white-collar occupations is neither inherently better nor unproblematic. Whereas white-collar work offers material and status benefits, blue-collar work can offer a host of its own unique rewards. These rewards include feelings of satisfaction that come from creating a tangible product, a strong self-identity tied to performance of physical labor, and the ability to "clock out" and leave work be- 
hind at the end of the day (Gibson \& Papa, 2000; Lucas \& Buzzanell, 2004; Thomas, 1989). Additionally, some blue-collar work-particularly skilled labor-rivals white-collar work in terms of material reward as it is in high demand and highly paid (e.g., welders, see Bureau of Labor Statistics, 2008). Combined with the decline of the quality of work life for white-collar workers (Fraser, 2001), blue-collar work may in fact be more intrinsically rewarding and a better occupational choice for some individuals.

Furthermore, social mobility can be problematic on an affective level. It has been tied to ensuing feelings of ambivalence (Connidis \& McMullin, 2002; Lucas, 2009; Luscher, 2004; Sennett \& Cobb, 1972), as individuals struggle with liminal class identities. For example, Lubrano (2004) interviewed more than 100 white-collar professionals from blue-collar families. These "straddlers," as Lubrano dubbed them, disclosed deep feelings of limbo-the emotional discomfort of feeling as though they have one foot in each social class, but not belonging fully to either. In their heartfelt accounts, individuals described interactions with family members that encouraged mobility, yet sometimes chided and excluded them once mobility was achieved. Kaufman (2003) describes the complex communicative negotiations made by individuals aspiring towards social mobility. In order to gain reciprocal middle-class membership (i.e., where individuals personally identified and were identified by others as middle class), they had to change their patterns of speech and dress, as well as sever ties with childhood friends. In short, social mobility is a complex process, replete with benefits and drawbacks. However, given the material drawbacks to blue-collar work identified above, social mobility (i.e., marked by postsecondary education, nonmanual occupations, knowledge work) is positioned here as a desirable, although not wholly unproblematic, socialization outcome.

\section{Family as a Key Source for Organizational Socialization}

These family connections to social mobility and reproduction can be understood as a form of organizational socialization. Jablin $(1982,1985,2001)$ describes organizational socialization as a life-span, stage-based, and inherently communicative process by which people learn about the jobs they hold, the careers they develop, and the organizations to which they belong. In particular, Jablin (2001) explains that the first stage of socialization - anticipatory socialization-begins in childhood and marks the point where individuals "form expectations about careers, jobs, and organizations prior to entering them" (p. 262). As they grow up, children and adolescents intentionally and unintentionally gather information they ultimately will use to determine the nature and direction of their respective careers (see also Van Maanen, 1976). During the anticipatory stage of socialization, communicative interactions influence individuals' vocational choices and prepare them for the world by exposing them to communication-related work principles.

Breaking away from the stage-model approach to socialization, Lair (2007) forwards an alternative model for understanding how individuals are socialized into the world of work. Lair argues that given the changing nature of work-from the 
"organization man" model to more individualized careers - socialization must be conceptualized more broadly as well. The model he proposes is one in which individuals move from broad-based socialization of work ideologies through narrowing socialization experiences (i.e., from work and vocational identity development to anticipatory socialization to organizational assimilation). This model requires attention be paid to the prework experiences and messages received by individuals from a variety of sources. Therefore, instead of socialization beginning at the point of occupational and organizational choice and moving linearly through stages of entry and exit, Lair's model proposes that individuals are socialized into an ideology of work, the role of organizations in their lives, and eventually narrowed to their own individual occupational and organizational socialization.

Even though the Jablin and Lair models are notably different, both open space for the involvement of family in the socialization process. Jablin (2001) states that families are a primary source from which these young people draw to establish expectations regarding their future work experiences (other sources include educational institutions, peers, media, and part-time work experiences). Family-based interactions such as dinnertime conversations (Paugh, 2005) and storytelling (Langellier \& Peterson, 2006) can teach youth what kinds of work are valued, set standards for future job performance, and establish individual aspirations and expectations. Likewise, Lair's model provides for lifelong socialization, including interactions with family prior to occupational and/or organizational encounter (for an example, see Gibson \& Papa, 2000).

\section{Paths of Socializing Messages}

Especially in family contexts, socializing messages can come in a variety of forms: conversations, advice, storytelling, and parental job spillover, to name a few. Vangelisti (1988) raises important concerns regarding paths of messages during anticipatory socialization, particularly as those messages are related to/influenced by their respective sources. She is concerned with comparisons being made between different sources of messages (e.g., parents versus peers), specifically because of the paths that those messages can take. That is, some messages are communicated explicitly and others implicitly (which she describes as "more ambient, less planned, and less directive"). Ultimately, she cautions researchers against grouping explicit and implicit messages together in socialization research until further research is done on the differences between these message types. She calls for future research to address these issues, in part, by asking: "Are the socialization messages under study communicated implicitly or explicitly to the adolescent?" (Vangelisti, 1988, pp. 477-478, emphasis added).

One recent study that looked at implicit and explicit messages is Dallimore's (2003) examination of the influence of socializing communication on new faculty members. She uses a memorable messages framework, which includes two unique message paths: "discrete" (explicit, direct) and "ambient" (implicit, indirect) messages. She defines ambient memorable messages as memorable personal experiences. She also includes "memorable absences," which although she does not define the 
term explicitly, appear to reflect either experiences of being excluded from conversations or topics of conversation perceived to be strategically avoided. Bradford, Buck, and Meyers's (2001) study also touches on message paths. In this study, women were surveyed about what their fathers and mothers communicated about career success, as well as how it was communicated, including direct communication (including expressions of support) and communication by example. They conclude that mothers communicate most frequently with direct communication and fathers by example. Likewise, Medved, Brogan, McClanahan, Morris, and Shepherd (2006) tapped into message paths when they asked participants whether work-life messages were "said directly to them." Although data were not reported on the path of the messages analyzed, Medved et al. (2006) state, "Direct or indirect messages from parents are also an early source of information about attitudes toward work and occupational choice" (p. 165, emphasis added).

Despite various researchers acknowledging the existence of multiple message paths, there does not appear to be complete consensus on what paths messages can take. Further, message paths are not taken as seriously as they could be. What is meant by this is that messages paths occasionally are identified and/or commented on when reporting results from research, as described above. However, researchers have not systematically raised and answered questions to further our insight into anticipatory organizational socialization processes and outcomes as related specifically to message paths (e.g., Which paths are most influential?). A necessary starting point for taking message paths seriously is to develop some consensus on which paths messages can take. As such, the first goal of this study is to identify systematically all available message paths.

RQ1: What are the different paths of socializing messages that individuals receive from family members?

\section{Content of Socializing Messages}

The content of socialization messages comes into play in a major way when it comes to social mobility and reproduction. Parents are likely to have a significant impact on whether their children experience social reproduction or mobility. In addition to the cultural capital and economic resources they provide, the way they communicate with their sons and daughters can play a pivotal role in career-based socialization. Serravallo (2004) asserts that families play a central role in the "mobility socialization" of younger generations. He explains that through their words and deeds, certain working-class parents - but certainly not all working-class parents - present to their children a vision of mobility that includes encouragement of education, promotion of middle-class occupations, and discouragement of manual labor. This transmission of values provides a guiding framework for social mobility that still enables choice on the part of the individual being socialized.

An example of parental communication that encourages social mobility is found with Bradford et al.'s (2001) research on successful White and African American businesswomen. They determined the content of parental messages shaped the women's 
sex-role socialization, encouraged achievement, and set personal standards for success, all which ultimately facilitated social mobility. On the flip side, Gibson and Papa's (2000) research on socialization in a blue-collar manufacturing organization reflects family communication that influenced social reproduction. They found that employees who had family members who worked at a local manufacturing organization had an easier time assimilating into the workplace-and its masculine culture - than those employees who did not have family ties to the plant. Put another way, newcomers who had experienced family-based anticipatory socialization identified more readily with the organizational goals, job tasks, and working conditions of the factory. Gibson and Papa credit the ease of workers' transition (which they termed "organizational osmosis") to preexisting socialization experiences that occurred largely in the home. That is, employees already had adopted from their relatives the ideas, values, and culture of the manufacturing organization before they began formal, paid employment with the company. In other words, the content of their messages was one that eased social reproduction.

Learning about the content of messages exchanged in working-class families can provide valuable insights into important sociological processes. In particular, it is necessary to examine both the messages communicated and how those messages are interpreted by recipients.

RQ2: Taking a holistic look at messages from all paths, what messages are communicated in blue-collar families regarding social mobility and reproduction?

\section{Method}

This study is part of a larger project that examined the careers and family-based socialization of a cohort of midcareer adults whose parents worked in the mining industry. These individuals came of age during periods of heavy deindustrialization in their hometown in the early 1980s. As such, they experienced severely limited access to employment in the local area due to major downsizing and industrial closures, which prompted them to purse starkly different kinds of work than previous generations. The broad aim of the study was to gain understanding as to how familybased communication (including storytelling, lessons, advice, memorable messages) shaped day-to-day experiences of and expressions about work, affected ongoing career identities, and ultimately helped and hindered these individuals as they transitioned into postindustrial careers.

In order to document diverse variations and identify important common patterns, a purposive, maximum variation sample was recruited (Kuzel, 1999). Initial recruitment tactics included an e-mail to members of an online alumni network that represented all high schools in the community, flyers posted on public bulletin boards (e.g., grocery stores, banks), and news stories and publicity in the local media. Additional recruitment was done via network and snowball sampling.

The primary participants for this study were 25 midcareer adults. They were evenly split among several key characteristics: sex (13 male; 12 female); age (average age was 
37; range 32-41); and geographic location (13 moved away; 12 lived in their hometown). Their educational attainment ranged from high school diplomas through graduate degrees. They worked in a variety of industries, including financial, medical, engineering, nonprofit, education, military, corrections, and construction/skilled trades. Additionally, primary participants' fathers $(n=20)$ and mothers $(n=16)$ were interviewed. Parent participants ranged in age from their early 50s through their early 80s. All the fathers self-identified as blue-collar mine workers. The mothers' careers spanned from full-time homemakers to part-time service work (e.g., retail, secretarial) to full-time professional careers (e.g., nursing, bookkeeping). One mother worked in the mines as an office employee. All but one father and four mothers currently were retired.

In-depth, semistructured interviews were conducted with participants at the site most comfortable and convenient for them (e.g., homes, restaurants, bookstores, workplaces). Additionally, 10 phone interviews were conducted with people who lived out of the area (in-person and phone interviews revealed equally rich information). When specifically requested, parents were interviewed as couples. In total, 53 interviews were completed, tallying more than 60 hours of recorded talk.

The semistructured interview protocol focused on three primary domains of questions: (a) occupational history and decision-making, (b) family-based socializing communication, and (c) on-the-job experiences that related to those messages. To tap into family-based socializing communication, participants were asked to recall specific messages regarding work/career that they received from their parents. They also were asked questions relating to what they learned from their parents and follow-up probes to query into how they learned those lessons (e.g., "What did you learn about work/career from your parents?", "How did you learn that particular lesson?," "Was it something they said?"). Parents were asked similar questions ("What stories do you remember telling your kids about work?" "When your kids talked about what they wanted to be when they grew up, what advice did you give?" "What did you want them to learn?").

Interviews were transcribed and verified against the original recordings. Due to the level of data analysis, the goal was to have near verbatim transcripts. Therefore, disfluencies (e.g., "um," "uh," stuttering), side conversations (e.g., when a server would ask if we wanted a refill), and the like were not transcribed. Important gestures, laughter, and vocal forcefulness were noted in brackets. Participants' names were replaced with pseudonyms and family members' transcripts were crosschecked to ensure all real names were masked. In total, transcription resulted in more than 1,000 pages of single-spaced text.

The first step in the analysis was to identify every family-based message. To be counted as a message, a unit of talk had to meet one of the following criteria derived from the memorable messages definition (Knapp, Stohl, \& Reardon, 1981; Medved et al., 2006; Stohl, 1986): (a) the participant quoted the specific words a parent had said, which reflects that memorable messages are remembered for a long period of time; or (b) the participant explained a lesson learned from a parent, even if an associated, discrete message was not recalled, which reflects that memorable messages are perceived to have a lasting influence on the recipient's life. From the data, 346 messages 
from parents were identified. The messages were then sorted into a typology of message paths, guided in part by extant message classification systems (e.g., Bradford et al., 2001; Dallimore, 2003; Vangelisti, 1988).

The second stage of the analysis was to search for themes within the data. This stage began with several iterative rounds of open, axial, and selective coding, placing primary focus on the messages themselves and the context in which the messages were shared. Miles and Huberman (1994) recommend cross-case matrices for deepening understanding and explanation of particular phenomena. Cross-case data matrices - which reduce the data in a manner that patterns within and between the cases and the codes can be identified - were built using the coded text units. Each case consisted of the adult son or daughter, the messages he or she recollected, as well as any messages his or her parents reported sharing. The data then were analyzed with a multiple exemplar case-oriented approach (Denzin, 1989), in which multiple cases are collected and examined closely to identify essential elements, patterns, or components.

\section{Findings and Interpretation}

The two assumptions of this analysis must be stated at the outset. First, because the aim of the overall project was to gain understanding of how a particular cohort transitioned into postindustrial careers (because mining jobs were no longer available in the local area), primary participants' narratives garner most of the attention. However, their responses also were analyzed carefully in light of their parents' related answers. Second, although admittedly oversimplified, for the purposes of this particular analysis, social mobility is conceptualized as pursing a white-collar profession and/or some other type of occupation that requires a college education; social reproduction is conceptualized as pursing working-class jobs that do not require a college degree. Based on this distinction, 15 participants experienced social mobility and 10 social reproduction.

\section{Socializing Message Paths}

Throughout the interviews, participants recalled many communicative exchanges with parents from which they drew lasting lessons for their careers. These potentially socializing messages emerged in a range of ways: advice, family stories, memories about school or work, expressions that their parents used, and eavesdropping on their parents' conversations, to name a few. Participants reported that many of these messages had a lasting impact on their occupational choices and the way they approach their work and/or make work decisions. In response to RQ1, which asked what paths family-based socializing messages can take, four categories emerged: direct, indirect, ambient, and omission. See Table 1 for a summary and frequencies.

First, the direct path includes those messages that are directed toward an individual and specifically address his or her future career and education. Direct messages came in the form of advice, gentle or not-so-gentle prodding to pursue education or a 


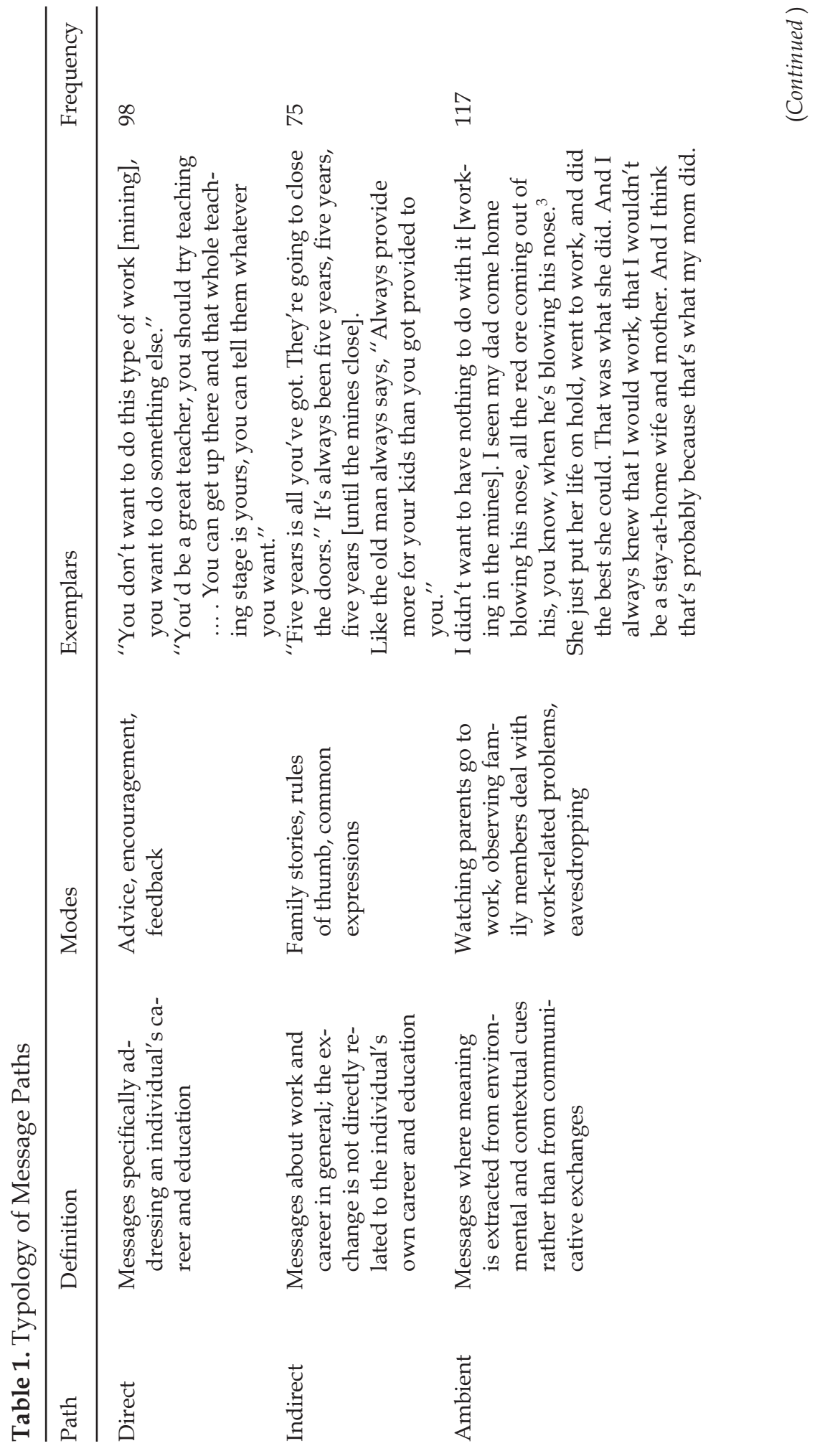




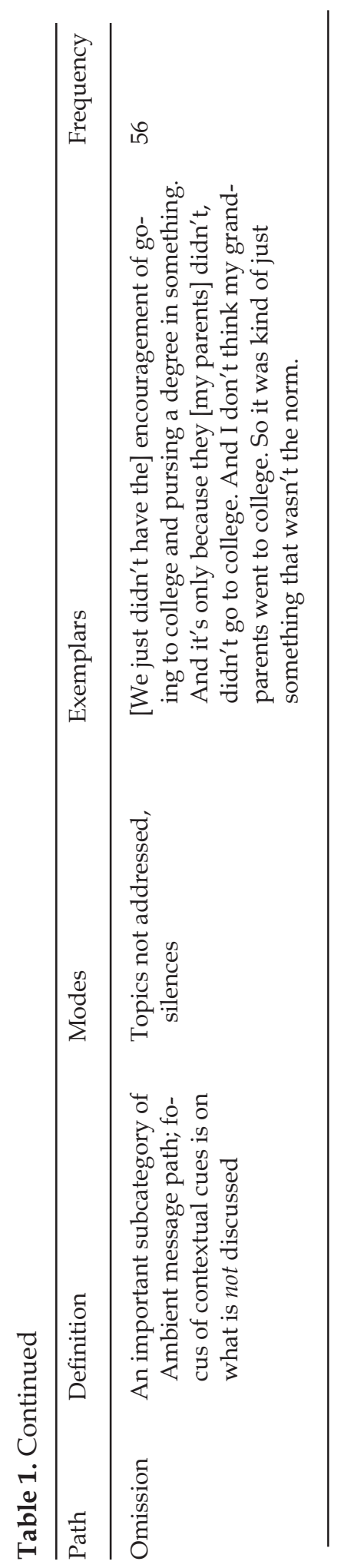


particular line of work, and encouragement and/or feedback regarding career-based decisions. Examples of these messages included both advice on what kinds of careers to pursue and what careers to avoid. Second, the indirect path includes messages in which someone communicates with an individual about work and career in general, but the exchange is not directly related to that individual's career or education. Indirect messages tended to come in the form of stories about parents' work experiences, adages about work, and general advice and rules of thumb about work that are not individually focused.

Third, the ambient path is a route by which an individual extracts meaning from environmental and contextual cues rather than engaging in a communicative exchange. Although these messages are not spoken, powerful conclusions are drawn. To be identified as an ambient message, an individual had to draw an explicit connection between a career outcome and a particular family-related observation. Ambient messages came from watching parents go to work, observing family members deal with work-related problems, and even stepping back and examining the larger context (e.g., community issues). Finally, a specific type of ambient message path is worth highlighting: omission. Omission messages are those messages in which the meaning is drawn from what is not discussed. Most often, omission messages dealt with education.

\section{Socializing Message Content}

The second phase in this study was to analyze the content of the socializing communication. Attending to messages from all three paths was vital for fully understanding socialization related to social mobility and reproduction. Certainly, there was variation between the families. Some parents strongly encouraged their children to pursue particular lines of work, others steered their children away from particular occupations. Some talked frequently about the importance of college, others did not talk about college or any form of higher education at home. Additionally, there were several common themes among the family-based messages (e.g., work hard, education is important, find a job you enjoy).

Family-based messages that address work, career, and education are messages that inherently are linked to social mobility and reproduction. When blue-collar parents encourage their children to go to college, they are positioning them to pursue careers that (hopefully) will advance their social-class status. When, in contrast, they encourage their children to bypass further education to take a job that relies on physical strength and skill, they are positioning them to experience social-class reproduction. Below, I provide some detailed excerpts that highlight mobility and reproduction messages.

\section{Mobility messages}

Harold, a retired miner, was very clear on his position that he did not want his children to follow in his career footsteps. In addition to encouraging his daughter, Heather, to be a teacher and prodding her with the comment "your waitress uniform 
is waiting" when she would complain about college, he also was explicit in his opinions about working in the mines. Heather explained:

He always said, "This is not the life I want for you guys. It provided me a good living," he said. "But there's better for you. You don't have to be in this mine with this dirt and this dust and the accidents." He wanted us all to go to college and get degrees and do something besides mining. He did not want us to be in the mine.

Sarah had a college degree and was a marketing manager at an international corporation. Her father, Sam, explained that he gave Sarah and her siblings the encouragement to seek more fulfilling jobs than those offered by the mining industry:

[If my kids stayed here and worked in the mines] that wouldn't bother me. But I knew the potential that they had. And I told every one of them-I don't know if they can remember it - but what I always told every one of them is, "Go out and try something. You can always come back. Go out there," I said. "You can always find something that might even be better. As far as I'm concerned, I'm happy where I am. If you're not, go try it ... I always, I definitely always wanted my kids to try something different. Try it different. Because I knew what they did in school. You know, school was so easy for them. Just go out and try it.

In both examples above, fathers gave direct messages to their children to pursue careers other than in the mines. In Heather's case, Harold was very specific. She recollected her father prodding her specifically to consider teaching as an occupation. In Sarah's case, the advice was more general, but still geared towards a college degree and professional career. Another important aspect about these mobility messages was their explicit call to do something other than mining.

\section{Reproduction messages}

In contrast to the direct messages that encouraged mobility, messages privileging reproduction were made by omission. Moreover, the omissions raised by primary participants tended to center on postsecondary education. Frank, who enlisted in the military immediately following high school graduation, ${ }^{2}$ said:

No, no college really wasn't discussed in my family. You know, the option was there. But it wasn't pushed, I thought, or as much as I thought it should have been, maybe. Then again, Mom didn't have a degree. Dad didn't have a degree.

Frank's comments and his rationalization (i.e., that his parents did not go to college) was a common theme. Victoria, who also joined the military, said essentially the same thing as Frank. She, too, believes that her parents not discussing postsecondary education options with her contributed to her slow career progression:

I honestly think that my parents should've talked about going to school. I think that it should've been more of an issue. I don't recall - I'm not saying it didn't happenbut I don't recall ever sitting down when I was a senior in high school and saying, you know, we should go and tour some of the colleges around the state and see where would you like to go. Or what are you thinking to major in? Or, you know, 
what are your intentions? ... And I don't feel like I had any of that. So, and again, I'm not trying to sound like, oh, poor me. But I just really don't, I don't recall them ever stressing education. And that is something that I wish would've been done .... I don't know. I just think I probably could have accomplished more.

What was notable about reproduction messages is that they were communicated mostly by omission. No one recalled a parent saying directly, "Don't go to college." In other words, it was not that parents intentionally shut down opportunities for their children. Instead, in some cases, they simply presented fewer options in their daily discourses.

\section{Impact of Message Paths on Meaning Negotiation}

Socializing messages in these blue-collar families often were far from clear, straightforward, and unambiguous. Instead of polarized cases in which some families strongly encouraged mobility and others did not, what existed were complex tangles of contradictory messages of mobility and reproduction. Not only were both types of messages present in various interviews, but both frequently were evident in single interviews, and sometimes even present in the same message. Below, I present three exemplar cases that highlight mobility-reproduction contradictions. The first case is a woman whose parents sent her contradictory messages at home about education. The second case is a man whose mother and father presented competing and contradictory messages from one another. The third case is a man whose father communicated a host of messages that simultaneously beseeched and bemoaned mobility. See Table 2 for a snapshot summary of each case. By presenting an array of messages in juxtaposition with one another, the table visually depicts how contradictions can emerge when messages from different paths are pulled together for purposes of overall sense-making.

\section{Exemplar Case 1}

Lisa is a midcareer adult who has slowly moved up the corporate ladder for the past 15 years, from clerical positions to her present position, one considered entry-level for recent college graduates. Lisa believes that her progress in the company could have been much swifter had she earned a college degree. Yet, there appears to be some disagreement with regard to the messages she received while growing up about higher education. Lisa's father said that he repeatedly told Lisa and her siblings to "go to college." Lisa remembers those conversations differently: "My dad always said that he wasn't going to put an average student through college. And I was an average student."

At first glance it might be easy to conclude that one of them is misrepresenting the situation. Either Lisa is shifting the blame for not going to college from her own lack of gumption onto her parents' lack of support or her father is presenting what he believes to be a socially desirable response when put on the spot by an interviewer. But, when taking a more holistic look at the messages Lisa received at home, another picture emerges. That is, these contradictory messages could have 


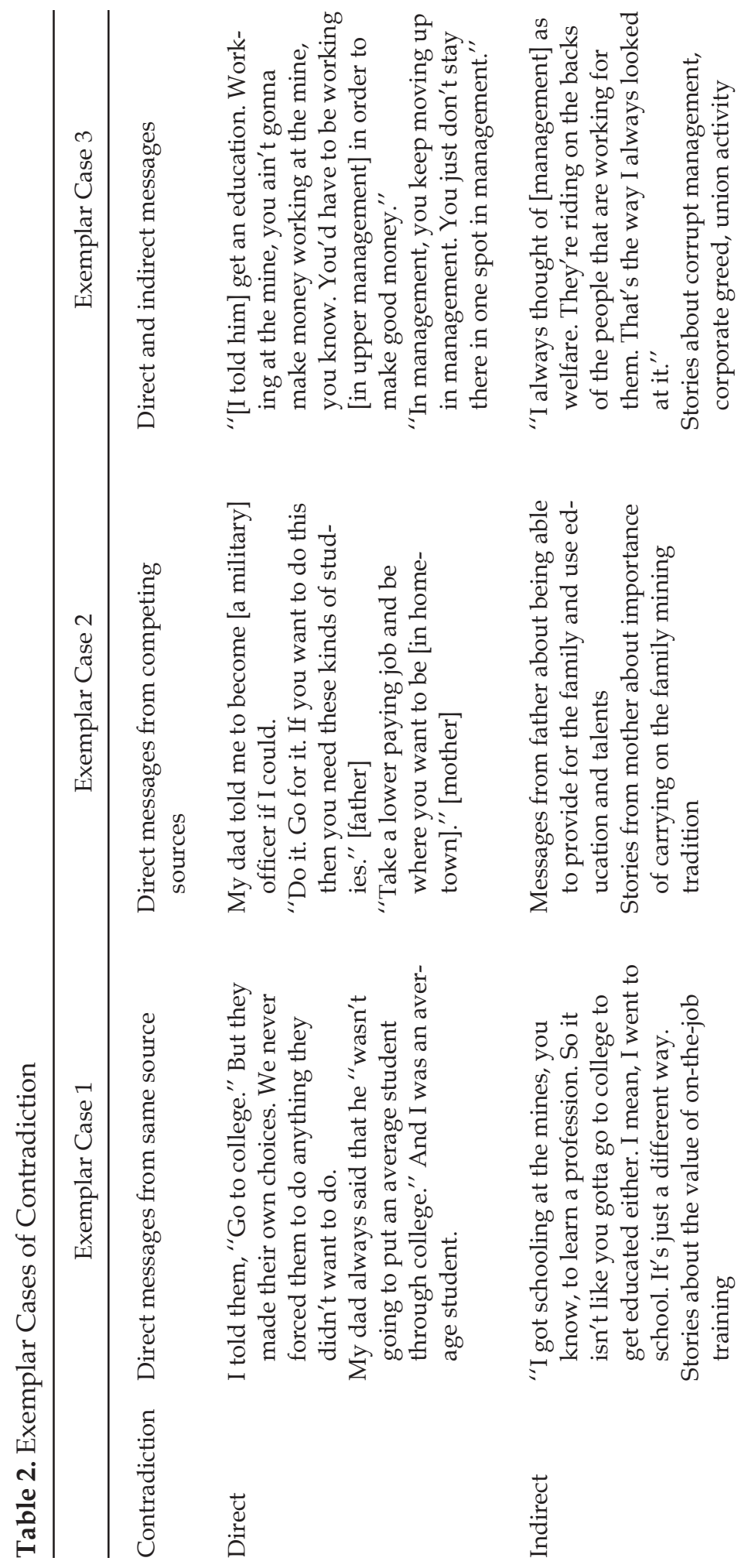




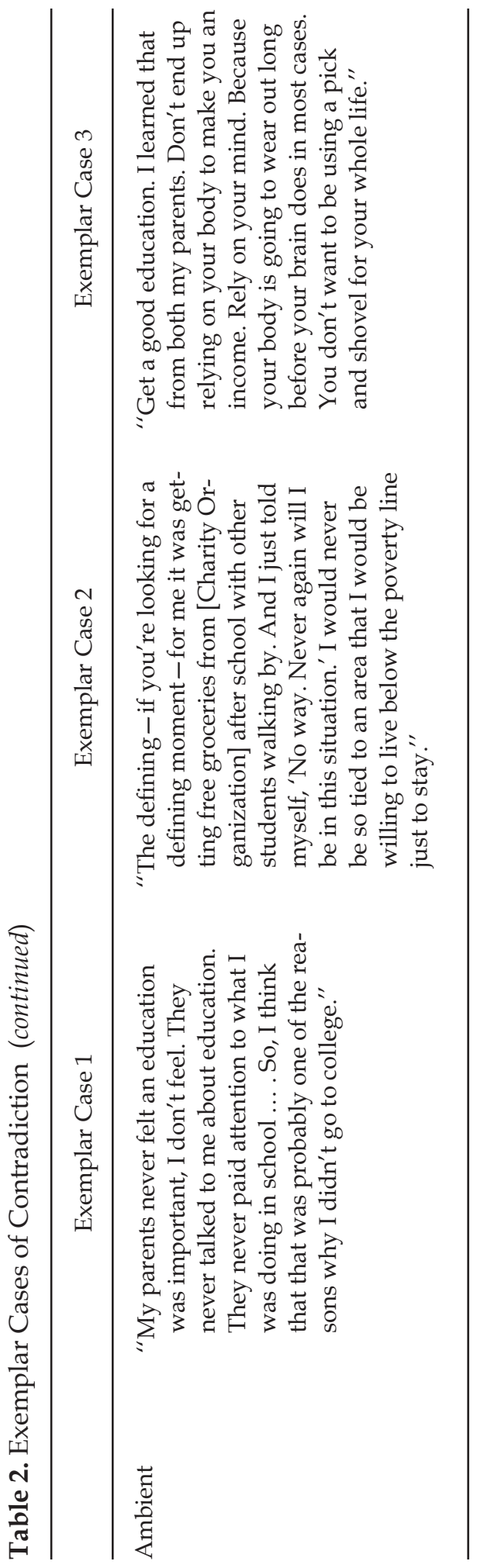


occurred with some regularity and Lisa still could have derived a conclusion that clearly privileged one perspective (reproduction; no college) and silenced the other (mobility; college).

Lisa's parents were proud of their personal accomplishments, particularly in light of neither of them attending college. Her father explained that he "got schooling at the mines, you know, to learn a profession ... I mean, I went to school. It's just a different way." Lisa's mother bypassed college also. She said, "I self-trained in all my jobs" and "I taught myself." Although indirect messages like these are not specifically directed towards Lisa, they carry a strong moral lesson: It is better to get training on-the-job than to go to college for a formal education. In fact, when her mother mentioned during the interview that Lisa wishes she had gone to college, her father justified her not going by explaining that she, too, was provided an education by her employer through various training sessions she attended.

Not only was it likely that Lisa received indirect messages such as these while growing up, she also recognized the omission of messages about the value of education:

My parents never felt an education was important, I don't feel. They never talked to me about education. They never paid attention to what I was doing in school ... . So, I think that that was probably one of the reasons why I didn't go to college.

When looking at direct messages alone, Lisa's case is highly contradictory. However, looking at the whole set of messages together, the contradiction is downplayed to the point of nearly being silenced. That is, the indirect messages Lisa's parents sent about the value of on-the-job training and the ambient messages she received by their omissions largely drowned out their direct messages that encouraged social mobility. This kind of contradiction has important consequences because it shows how direct messages can be disregarded when competing messages from different paths are present-even if those messages are unintended.

\section{Exemplar Case 2}

Nathan is an upwardly mobile leader with extensive overseas experience. He claims that he "always knew" he was going to move away from the mining town in which he was raised, telling himself as early as 12 years old, "I'm getting out of here if it's the last thing I do." At home, however, Nathan's ambitions received mixed support from his parents. Whereas Lisa's parents presented a unified (although internally contradictory) front, the opposing themes and perspectives in Nathan's family came from his mother (a substitute teacher) and father (a miner) who took opposite sides of one another. Although his mother had what could be considered a middle-class career, she took pride in her family's mining tradition that spanned four generations. For her, mining "was a way of life." His father, who was a miner by trade, did not share her same fascination. They competed with each other when giving Nathan and his siblings advice about their careers.

Nathan clearly recognized and articulated the ongoing tensions and contradictions between his parents, beginning with their hopes for him and his brothers (not) 
continuing the family mining tradition:

My dad didn't want us working in the mines. [But] my mother, she actually really wanted us to land jobs in the mine. And I think to her, even though she was educated, it was just sort of a natural thing. The men went to work in the mines.

Despite the competing messages he received from his father (mobility) and mother (reproduction), ultimately, it was an ambient message that tipped the scales. The family struggled financially throughout the recession of the early 1980s when the local mines shut down, as well as for an extended period after the mines reopened, as his father was low in seniority and near the bottom of the callback list. Nathan described the experience this way:

I mean the layoffs were terrible. Just because there's no job market to absorb it. I mean, really, the defining - if you're looking for a defining moment-for me it was getting free groceries from the thrift store after school with other students walking by. And I just told myself, "No way. Never again will I be in this situation." I would never be so tied to an area that I would be willing to live below the poverty line just to stay.

During this period, when Nathan was approaching high school graduation, his father encouraged him to pursue a professional career that would enable him to be a better provider. His mother regularly expressed her desire that he carry on the family mining tradition. Although Nathan followed his father's advice, Nathan saw the strong appeal of his parents' respective opinions, which were regularly communicated to him through direct and indirect paths. However, it was absorbing ambient messages that came from watching his family struggle with making ends meet that helped Nathan negotiate the contradiction and pursue social mobility. What is significant about the kind of contradiction in this case is that it arose between two sources. This kind of contradiction may be particularly difficult to negotiate because it, in a sense, asks an individual to "pick a side." Therefore, there could be added stress for individuals knowing that one person was let down or felt betrayed by the choices made. As such, there may be additional communicative demands placed on the child to engage in relational maintenance and/or repair.

\section{Exemplar Case 3}

Adam is a professional in the medical industry with a lucrative career. He made a circuitous path to his present position - including one that took him through a several-year stint of working-class jobs. He received many messages about work and career from both his parents, but particularly from his outspoken father. As Adam has climbed his way into managerial positions, he relied on past messages from his parents to guide his decision-making, as well as sought their advice and input along the way.

In Adam's case, his father was consistent in his direct messages. He wanted Adam to be as successful as possible, both in terms of earning a good salary and climbing the corporate ladder. His father regularly encouraged Adam to make the sacrifices 
necessary to get an education and a good job. He also encouraged Adam to pursue promotions into management: "In management, you keep moving up in management. You just don't stay there in one spot in management."

The contradictions in Adam's case arose from his father's messages about management. While encouraging Adam to become a manager, his father, in the same breath, frequently talked of his distrust and dislike of management (particularly at the mines). As a prounion laborer, he spoke at length about corrupt management, corporate greed, arrogance, and incompetence, stories and rants to which Adam was exposed. One example of this is when he said, "I always thought of management as welfare. They're riding on the backs of the people that are working for them" and repeatedly called managers "welfare bums."

Mixed messages such as these understandably could cause ambivalences to arise, if not stunt career progression and social mobility. In terms of ambivalences, it is possible that Adam could struggle with coming to grips with his position, being both proud of his success, yet feeling that he somehow betrayed or disappointed his father by joining management ranks (see Lubrano, 2004; Sennett \& Cobb, 1972). In terms of career progression, it also is possible that Adam could have resisted career advancement into management ranks by actively avoiding the very positions his father disparaged. Yet, Adam was largely unfazed about the contradictions. He may have been assuaged by the ambient messages he received from his parents about the importance of education. When asked what he learned about work from his parents Adam recalled an ambient message about the importance of education:

Get a good education. I learned that from both my parents. Don't end up relying on your body to make you an income. Rely on your mind. Because your body is going to wear out long before your brain does in most cases. You don't want to be using a pick and shovel for your whole life.

This was one lesson Adam's father did not have to express in words. Like his father before him, Adam's father received an involuntary medical retirement from the mine after years of back-breaking labor. Therefore, the ambient messages and direct messages for which Adam was a recipient worked in tandem to erase any ambivalences that may have arisen from indirect messages scorning management and, by extension, Adam's social mobility.

Even though direct messages about his own career were very specific and unidirectional (i.e., pointing unequivocally to social mobility), Adam also was witness to many stories and ambient messages that positioned managers as the enemy of the working people. This kind of contradiction - where advice to the child was for mobility, but indirect and ambient messages offered sharp critiques of people from upper classes - appeared to be quite common. It is this very kind of contradiction that may be responsible for many of the residual ambivalences tied to social mobility (Lubrano, 2004; Sennett \& Cobb, 1972).

These three exemplar cases highlight the different paths that socializing messages can take. Messages that had a lasting impact on career choices followed direct, indirect, and ambient paths. Moreover, these cases draw attention to the ways that contra- 
dictions can occur. Not only can contradictions arise between direct messages from the same source (e.g., Lisa's father encouraging and discouraging college), but contradictions may arise between family sources (e.g., Nathan's mother and father delivering different advice). Further, contradictions may manifest themselves more subtly when a particular outcome is both held up as something to be pursued and something to be admonished, as in the case of Adam's father encouraging him to pursue a management career while simultaneously discrediting management. Consequently, examining socializing communication from a more holistic vantage point offers a new perspective on understanding the complex relationship between communication and social mobility/reproduction.

\section{A Note on Gender}

There were differences between the messages sent to sons and daughters, particularly regarding attitudes towards working in the mines. In this community, mining was viewed as undesirable for women and women as unfit for mining (Lucas \& Steimel, 2009). Therefore, even though they may have received contradictory messages of social mobility and reproduction in a broader sense, no female participants were encouraged to pursue a career in mining specifically. For instance, when asked how they would feel if their children pursed mining careers, parents' answers only acknowledged their sons. Gail said, "I would never discourage them, I wouldn't," but then talked specifically about her two sons and did not mention her daughter, who was one of the interviewees. Jim, whose daughter and son were both interviewed, said, "I wouldn't have any problem with that, but I don't think he [emphasis added] would ever enjoy it because he doesn't like to do what I used to do." Kenny, whose daughter was interviewed for the study, also shifted the discussion to his son, saying,

I guess I wouldn't have any problem with it, you know, if that's what he wanted to do in order to stay in the area. [My son is looking for work] and in the interim if he wanted to work at the mine, I wouldn't have any problem with it.

Parents who had only daughters did not have the ability to shift the frame of the question to their sons. In these cases, their objection to their daughters pursuing mining careers became more explicit. Vincent, who explained that the mines provided some of the best wages in the region explained that "the ladies" started working at the mines and "they got very nice pay." But he quickly countered this observation by saying several times "I wouldn't have wanted them [my daughters] there." By excluding their daughters from their answers and, at other times, by directly addressing the undesirability of mining for women point to the likelihood that the socializing communication to which daughters were exposed barred the possibility of mining as a viable option.

In contrast, it was considered acceptable, if not desirable in a few cases, for sons to follow in the "manly" footsteps of their mining fathers (e.g., being strong, being a hard worker, being the family breadwinner). For example, Nathan's mother (who 
was a college-educated teacher) came from a long line of mining families. For herand many other people in this community - it was "natural" for men to mine. Despite being acutely aware of the physical dangers of mining and the instability of the occupation from a financial standpoint, she wanted all her sons to follow in her husband's, father's, and grandfathers' footsteps. Even in cases where there was no direct encouragement to pursue mining per se, highly gendered messages connected masculinity to work that is dirty, dangerous, and physically demanding. From Lair's (2007) perspective, these kinds of messages socialize individuals to specific (in this case, gendered) work ideologies that ultimately may affect vocational choices and organizational assimilation.

Therefore, the presence of direct messages that encourage sons to pursue mining, indirect messages that present mining as a desirable and "manly" occupational choice and/or as a worksite "unfit for ladies," and ambient messages that exclude mining as an option for daughters have important implications. These gendered messages are not necessarily mobility messages for daughters, as women could be socialized to alternative occupations that are neither socially nor economically advantageous. Nor are they always reproduction messages for sons. Instead, they are messages that add a dimension of complexity and contradiction for men. In particular, strong indirect and ambient messages about masculine work sites (Gibson \& Papa, 2000) could create a set of gendered expectations that would be more difficult to fulfill in white-collar roles (see Sennett \& Cobb, 1972). Further, it points to the distinct possibility that men who have achieved social mobility may have higher levels of ambivalences about class mobility than socially mobile women (Lubrano, 2004). If there are indeed social mobility/reproduction effects tied to gendered messages, then it is an area that requires further attention and research.

\section{Discussion}

In summary, family-based memorable messages about work and career emerged from stories about work, common expressions, (un)solicited advice, and contextual cues. The direct, indirect, and ambient messages exchanged in families and the meanings individuals extracted from their interactions had a powerful and lasting impact. As to the content of these socializing messages, the themes and perspectives had direct import for mobility and reproduction. Family-based messages that socialized or attempted to socialize children and adolescents for their upcoming careers, were not recalled as simple, unequivocal messages that pointed one direction or another. Instead, participants received a mix of often contradictory messages that encouraged social mobility (e.g., go to college, don't work in the mines) and social reproduction (e.g., college isn't necessary, pursue a working-class job).

It should not be surprising that contradictions were present, as contradictions emerge in a variety of complex family contexts, such as managing disability (Canary, 2008) or grieving the death of a child (Toller \& Braithwaite, 2009). What becomes more important than the existence of the contractions, however, is how individuals produc- 
tively negotiate them (see Baxter, 2006). In the case of career socialization, negotiations involve both agentic acts (e.g., enrolling in college, pursuing a particular career field) and discursive negotiations that influence meaning-making about and affective responses to their choices (e.g., sense-making about choices, pride, regret, ambivalence).

This research makes two key contributions. First, these findings demonstrate that socializing messages and the (co)construction of meaning occur via a variety of message paths, not only through explicit (i.e., direct) memorable messages. Therefore, it is important that communication scholars consistently look not only at simple exchanges (e.g., a memorable message told to a child by a parent or to a newcomer by a veteran), but instead at a more holistic account of communication that includes direct, indirect, and ambient messages (including messages by omission). Paying attention to direct messages alone may turn researchers' attention away from the impact and interplay of important lessons being received along multiple message paths. A more holistic approach can provide a more telling, nuanced account of how socialization occurs and how meanings are extracted from messages. From a practical standpoint, parents should be made aware that it is not just explicit talk about career choices that matters to their children. The stories they tell and their own observable work experiences/job spillover also have powerful effects on how kids are socialized to work ideologies and, ultimately, vocational choice (Lair, 2007).

Second, it is through the messages exchanged among blue-collar family members that both social mobility and social reproduction are constituted and negotiated. By placing communication at the core of socialization processes, this project highlights the fact that members of the next generation are not passive recipients of socialization messages. Instead, they are active co-creators of the socialization experience who attend to messages, actively seek advice, survey the environment for ambient messages, analyze what is said and not said, and derive meaning from the complex interplay of contradictory messages. As such, this research points to individuals' agency in accepting, transforming, and/or resisting those messages.

The participants' working-class backgrounds undoubtedly influenced the content of the socializing messages to which they were exposed. It is reasonable to expect that being raised in a blue-collar family had some bearing on what topics were discussed and how they were addressed. Further, it is possible that social class also influenced the paths their socializing communication followed. For instance, research shows that work is a more central life-interest for white-collar workers, and that bluecollar workers possess a much more instrumental attitude towards work and career in general (Thomas, 1989). As such, white-collar, middle-class kids may be getting more direct socialization messages from their parents, as work may be a more common topic of conversation in their homes than it is in blue-collar homes. If that is the case, blue-collar, working-class kids may be getting more of their information (and deriving more of their meaning-making) from indirect and ambient message paths, which could have important consequences, especially in terms of identifying career and education options. Because this study could only address the content and paths of the messages exchanged in blue-collar families, several questions remain unanswered: How does socializing communication differ between blue-collar and white- 
collar families? Are there class-based differences in the paths of messages that are communicated to working-class, middle-class, and upper-class families?

As with all research, there are limitations. The most notable weakness is that study did not take into consideration the influence of socializing messages from other sources, such as school, part-time work experiences, media, and peers (see Jablin, 2001). Undoubtedly messages from these sources affected the individuals in this study. Therefore, future research that examines work and career socialization/choices made by individuals should also take into consideration other message sources, their paths and content, as well as their relative influence. Additionally, the analysis relied on a sample of individuals from a racially homogenous (i.e., White) population. Although the sample was representative of the population (including variation in education level, career path, gender, geography), it did not represent any racial or ethnic diversity. Therefore, the transferability of results should be viewed with caution. Socialization research that engages the intersectionalities of class, gender, and race is another avenue for future discovery.

\section{Conclusion}

In conclusion, this study affirms the centrality of communication in displaying how socializing messages - replete with all their tensions, ambivalences, and contradictions - can account for mixed results from sociological studies on social mobility and reproduction (e.g., Willis, 1977). Working-class families exert a strong influence on their sons' and daughters' socialization to the world of work. However, that influence seldom is simple and unambiguous. Not only are the messages oftentimes contradictory, but the changing economic context in which the messages are embedded is growing increasingly complex. Anyone interested in issues of class should attend more closely to holistic accounts of family communication, as these complex webs of meaning serve as communicative pathways to social mobility and reproduction.

\section{Notes}

[1] "Blue-collar" is a designation for skilled, semiskilled, and unskilled industrial work and/or workers whose jobs are centered on physical labor of some sort. Blue-collar workers' wages can range from minimum wage for unskilled labor (e.g., cleaning, basic assembly) to sizable salaries for skilled work (e.g., welders, plumbers). Based on socioeconomic status alone, many bluecollar workers fit into a middle-class designation. However, conceiving of class in terms of capital-worker relationships (Zweig, 2000), the stability of access to resources over time (Perrucci \& Wysong, 2003), or as a set of shared cultural values (Kaufman, 2003), blue-collar work is most closely (albeit not perfectly) aligned with a working-class designation.

[2] More than a quarter of the primary participants in this study have previous military experience. Although this rate is high, it is representative of community population as a whole. The military is seen as a viable and desirable option for both vocational training and access to higher education.

[3] Working in underground iron ore mines was an extremely dirty job. Similar to coal miners who 
are covered in black soot after their shifts are over, iron ore miners are covered in a rust-colored dust called "red dust" by locals. This dust permeated their clothes, was absorbed by their skin (despite harsh scrubbing with abrasive soaps after work), and was breathed into their lungs. Frank's father did not have to tell his son it was a dirty job. Seeing the red dust coming out of his nose after every shift was message enough.

\section{References}

Ansberry, C. (2003, June 30). A new blue-collar world: Workers now need more skills but get less job security. Wall Street Journal, pp. B1, B4.

Baxter, L. A. (2006). Relational dialectics theory: Multivocal dialogues of family communication. In L. A. Baxter \& D. O. Braithwaite (Eds.), Engaging theories in family communication: Multiple perspectives (pp. 130-145). Thousand Oaks, CA: Sage.

Bertaux, D., \& Thompson, P. (1997). Introduction. In D. Bertaux \& P. Thompson (Eds.), Pathways to social class: A qualitative approach to social mobility (pp. 1-31). Oxford, UK: Clarendon Press.

Bluestone, B., \& Harrison, B. (1982). The deindustrialization of America: Plant closings, community abandonment, and the dismantling of basic industry. New York: Basic Books.

Bradford, L., Buck, J. L., \& Meyers, R. A. (2001). Cultural and parental communicative influences on the career success of white and black women. Women's Studies in Communication, 23, 194-217.

Bureau of Labor Statistics. (2008). Occupational outlook handbook 2008-09 edition. Washington, DC: U.S. Department of Labor.

Canary, H. E. (2008). Negotiating dis/ability in families: Constructions and contradictions. Journal of Applied Communication Research, 36, 437-458.

Chen, X., \& Carroll, C. D. (2005). First-generation students in postsecondary education: A look at their college transcripts. Washington, DC: U.S. Department of Education.

Clair, R. P. (1996). The political nature of the colloquialism, “a real job": Implications for organizational socialization. Communication Monographs, 63, 249-267.

Connidis, I. A., \& McMullin, J. A. (2002). Sociological ambivalence and family ties: A critical perspective. Journal of Marriage and Family, 64, 558-567.

Dallimore, E. J. (2003). Memorable messages as discursive formations: The gendered socialization of new university faculty. Women's Studies in Communication, 26, 214-265.

Denzin, N. K. (1989). Interpretive interactionism. Newbury Park, CA: Sage.

Fraser, J. A. (2001). White-collar sweatshop: The deterioration of work and its rewards in corporate America. New York: W.W. Norton.

Gibson, M. K., \& Papa, M. J. (2000). The mud, the blood, and the beer guys: Organizational osmosis in blue-collar work groups. Journal of Applied Communication Research, 28, 68-88.

Gilbert, D. (2008). The American class structure in an age of growing inequality (7th ed.). Thousand Oaks, CA: Sage.

Jablin, F. M. (1982). Organizational communication: An assimilation approach. In M. E. Roloff \& C. R. Berger (Eds.), Social cognition and communication (pp. 594-626). Beverly Hills, CA: Sage.

Jablin, F. M. (1985). An exploratory study of vocational organizational communication socialization. Southern Speech Communication Journal, 50, 261-282.

Jablin, F. M. (2001). Organizational entry, assimilation, and disengagement/exit. In F. M. Jablin \& L. L. Putnam (Eds.), The new handbook of organizational communication: Advances in theory, research, and methods (pp. 732-818). Thousand Oaks, CA: Sage.

Kaufman, P. (2003). Learning to not labor: How working-class individuals construct middle-class identities. The Sociological Quarterly, 44, 481-504. 
Knapp, M. L., Stohl, C., \& Reardon, K. K. (1981). Memorable messages. Journal of Communication, 31, 27-41.

Kohn, M. (1969). Class and conformity: A study of values. Homewood, IL: Dorsey Press.

Kuzel, A. J. (1999). Sampling in qualitative inquiry. In B. Crabtree \& W. Miller (Eds.), Qualitative methodology (2nd ed., pp. 33-45). Thousand Oaks, CA: Sage.

Laband, D. N., \& Lentz, B. F. (1985). The roots of success: Why children follow in their parents' career footsteps. New York: Praeger.

Lair, D. J. (2007, November). Rethinking the "organizational" in organizational socialization research: From ontological agent to discursive domain(s). Paper presented at the National Communication Association annual meeting, Chicago, IL.

Langellier, K. M., \& Peterson, E. E. (2006). “Somebody's got to pick eggs": Family storytelling about work. Communication Monographs, 73, 468-473.

Lareau, A., \& Conley, D. (2008). Social class: How does it work? New York: Russell Sage Foundation.

Lubrano, A. (2004). Limbo: Blue-collar roots, white-collar dreams. Hoboken, NJ: John Wiley and Sons.

Lucas, K. (2009, May). When the dream and promise collide: Accounting for class mobility-based ambivalences. Paper presented at annual meeting of the International Communication Association, Chicago, IL.

Lucas, K., \& Buzzanell, P. M. (2004). Blue-collar work, career, and success: Occupational narratives of sisu. Journal of Applied Communication Research, 32, 273-292.

Lucas, K., \& Steimel, S. (2009). Creating and responding to the gen(d)eralized other: Women miners' community-constructed identities. Women's Studies in Communication, 32, 320-347.

Luscher, K. (2004). Intergenerational ambivalence: Further steps in theory and research. Journal of Marriage and Family, 64, 585-593.

Medved, C. E., Brogan, S. M., McClanahan, A. M., Morris, J. F., \& Shepherd, G. J. (2006). Family and work socializing communication: Messages, gender, and ideological implications. Journal of Family Communication, 6, 161-180.

Miles, M. B., \& Huberman, A. M. (1994). Qualitative data analysis: An expanded sourcebook (2nd ed.). Thousand Oaks, CA: Sage.

Mishel, L., Bernstein, J., \& Shierholz, H. (2009). The state of working America 2008/2009. Ithaca, NY: ILR Press.

Morland, J. K. (1960). Educational and occupational aspirations of mill and town school children in a southern community. Social Forces, 39, 169-175.

Myers, K. K. (2005). A burning desire: Assimilation into a fire department. Management Communication Quarterly, 18, 344-384.

Newman, K. S. (1999). Falling from grace: Downward mobility in the age of affluence. Berkeley: University of California Press.

Paugh, A. L. (2005). Learning about work at dinnertime: Language socialization in dual-earner American families. Discourse and Society, 16, 55-78.

Perrucci, R. L., \& Wysong, E. (2003). The new class society: Goodbye American dream? (2nd ed.). Lanham, MD: Rowman and Littlefield.

Pitts, M. J., Fowler, C., Kaplan, M. S., Nussbaum, J., \& Becker, J. C. (2009). Dialectical tensions underpinning family farm succession planning. Journal of Applied Communication Research, 37, 59-79.

Rytina, S. (1992). Scaling the intergenerational continuity of occupation: Is occupational inheritance ascriptive after all?. American Journal of Sociology, 97, 1658-1688.

Sennett, R., \& Cobb, J. (1972). The hidden injuries of class. New York: W.W. Norton. 
Serravallo, V. (2004). Less alienated labor: A source of hope-filled mobility socialization?. Journal of Contemporary Ethnography, 33, 368-405.

Simpson, R. L. (1962). Parental influence, anticipatory socialization, and social mobility. American Sociological Review, 27, 517-522.

Stohl, C. (1986). The role of memorable messages in the process of organizational socialization. Communication Quarterly, 34, 231-249.

Thomas, R. J. (1989). Blue-collar careers: Meaning and choice in a world of constraints. In M. B. Arthur, D. T. Hall, \& B. S. Lawrence (Eds.), Handbook of career theory (pp. 354-379). Cambridge, UK: Cambridge University Press.

Toller, P. W., \& Braithwaite, D. O. (2009). Grieving together and apart: Bereaved parents' contradictions of marital interaction. Journal of Applied Communication Research, 37, 257-277.

Van Maanen, J. (1976). Breaking in: Socialization to work. In R. Dubin (Ed.), Handbook of work, organization, and society (pp. 67-130). Chicago: Rand McNally.

Vangelisti, A. A. (1988). Adolescent socialization into the workplace: A synthesis and critique of current literature. Youth \& Society, 19, 460-484.

Weinger, S. (2000). Opportunities for career success: Views of poor and middle-class children. Children and Youth Services Review, 22, 13-35.

Willis, P. (1977). Learning to labor: How working-class kids get working-class jobs. New York: Columbia University Press.

Zweig, M. (2000). The working class majority: America's best kept secret. Ithaca, NY: ILR Press. 